\title{
Driving Strategy or Just Going through the Motions: An Empirical Study of Boardrooms in the UK (note 1)
}

\author{
Sharon Kemp \\ Swinburne University \\ Locked Bag 218 Lilydale, Victoria 3140, Australia \\ Email: skemp@swin.edu.au
}

Received: October 12, $2010 \quad$ Accepted: November 3, $2010 \quad$ DOI: 10.5430/ijba.v1n1p2

\begin{abstract}
The level of interest regarding corporate board, their role and the contribution they make to organisation's performance and success has increased in the many global settings. There is however, a gap in our knowledge about what board members do. In order to have a better understanding of boards, we need to know more about the behaviour of those who sit on boards. Many chairmen and all non-executive directors serve on corporate boards in a part-time capacity; however, such part-time service does not negate a role in strategy. The purpose of this paper is to ask how, if at all, do part-time board members influence strategy in UK companies?

Data from interviews with 30 board members are interpreted using the 1999 framework of McNulty and Pettigrew which conceptualises part-time board members" involvement in strategy as "taking strategic decisions", "shaping strategic decisions" and shaping the content, context and conduct of strategy".

Part-time board members are able to shape both the ideas that form the content of corporation's strategies and the methodologies and processes by which those ideas evolve. In so doing, part-time board members are capable of exerting control over management and influencing processes of strategic choice and change. Boards of directors have a role in strategy formulation, strategic decision-making and strategic control.
\end{abstract}

Keywords: Boards of directors, Management strategy, Strategic choice

\section{Introduction}

There has been increasing interest both in the UK and on the world stage regarding corporate boards, their role and the contribution they make to organisations' performance and success.

Over the last 10 years there has been a surge of interest in boards of directors. Much of the interest, has been a reaction to governance irregularities and mismanagement in some UK companies such as Polly Peck, Coloroll, BCCI and of course the spectacular scandals of HIH, National Australia Bank (NAB) (Australia), Lehman Brothers, Enron, Worldcom, (US), and Parmalat (Italy). As indicated by Kiel and Nicholson (2005, p.613) "These failures underscore the fact that boards must be concerned with more than organisational and management performance: they also need to review their own performance". However, many boards do not undertake self-evaluation of performance and are therefore not aware of the corrective measures that they need to make to their conduct and behaviour. Kiel and Nicholson (2005, p.613) point to the fact that "governance failures may result in either a significant reduction in, or total destruction of, shareholder wealth".

Effective leadership by boards is seen as critical to developing and driving strategy through guiding change and ensuring effective implementation takes place (Kiel and Nicholson, 2005). Boards need to balance the corporation's needs for leadership and control and achieve good governance (Pound, 1995).

Large institutional investors are becoming increasingly active in demanding good governance in the belief that it will enhance corporate outcomes. There is an expectation that the board be proactive by intervening, particularly in the case of corporate crisis, to provide strategic guidance as opposed to a passive board who 'sits back and ticks boxes'. (Conger, Lawler, and Finegold, 2001) The board that goes through the motions and 'acts like a rubber stamp' provides a form of control at the expense of exercising leadership through the shaping of the content, context and conduct of strategy. As indicated by McNulty and Pettigrew (1999, p.55) "The board should develop the context for strategic debate, establish a 
methodology for strategic development, monitor strategy content and alter the conduct of the executive in relation to strategy".

Recent research has focussed on board structure, board composition and director compensation so that more is known about who sits in UK boardrooms, who they sit alongside, how much they are paid and how they are selected (Conyon and Peck, 1998; Conyon, Peck \& Sadler, 2001; Pye, 2001; Pass, 2004). There has been less focus on what boardmembers do. The structure and composition of UK boards is declared in company annual reports and other publicly available documents but behaviour in UK boardrooms is not as transparent. In fact few studies have managed to 'get inside the Black Box'. Dewally and Peck (2010) note that we have much more to learn about strategy-making processes at the company director and CEO level of companies. Additionally, Pye and Pettigrew (2005, S30) indicate that "we still know relatively little about how boards and directors actually behave or conduct their roles effectively".

To better understand boards, we need to know more about the behaviour of those who sit on boards. Many chairmen and all non-executive directors serve on corporate boards in a part-time capacity. It is suggested in the literature (Adams, 2002; OECD, 2004; Bathula, 2008) that such part-time service does not negate a role in strategy. Yet earlier research suggests that part-time board members are barely involved in strategy (Lorsch and MacIver, 1989). This paper asks how, if at all, do part-time board members influence strategy in UK public companies?

This paper firstly examines the literature on change and control as key aspects of firms' strategic conduct. Secondly, attention turns to generating empirical data to examine how part-time board members engage with these processes. Attention is given to the actions of part-time board members vis-a-vis executive directors, both inside and outside the boardroom. This paper builds on the previous work of Kemp (2006) which examined the role of board members in the Australian setting. This study aims to similarly study board members and highlight any differences in the UK setting.

Data from interviews with 30 board members is interpreted using the framework of McNulty \& Pettigrew (1999) which conceptualises part-time board members' involvement in strategy as: 'taking strategic decisions', 'shaping strategic decisions' and 'shaping the content, context and conduct of strategy'. Each of the three levels of part-time board member involvement in strategy described by McNulty and Pettigrew (1999) engage part-time board members in processes of choice, change and control in differing ways. Their research challenges the research findings of Oliver (2000) and Lorsch and MacIver (1989) suggesting that part-time board members simply ratify decisions made by executives. Rather, the McNulty and Pettigrew (1999) framework reveals "that part-time board members are able to shape both the ideas that form the content of corporations' strategies and the methodologies and processes by which those ideas evolve. In so doing, part-time board members are capable of exerting control over management and influencing processes of strategic choice and change". Other subsequent research (Forbes and Milliken, 1999; Carpenter and Westphal, 2001; Stiles, 2001; Hendry and Kiel, 2004; Roberts, McNulty and Stiles, 2005; McNulty, Roberts and Stiles, 2005) confirms that boards of directors have a role in strategy formulation, strategic decision making and strategic control. Van der Walt and Ingley (2001) suggest that there is an emerging need for the strategic contribution by the board in a dynamic environment. They indicate "the changing role of directors as moving the implicit paradigm away from the 'pathology' of governance [failures] to the strategic contribution for "fitness and survival"' (Van der Walt and Ingley 2001, p.184). This indicates that it has become increasingly important that boards are involved in corporate strategy. As indicated by Ingley and Wu (2007, p.126) "It also implies that as boards become more actively involved in influencing strategy development, they will thus have an impact on the process of strategic change in their organisations". The board's role is in the driver's seat not as a rubber stamp (Oliver, 2000). This view is further affirmed by Kiel and Nicholson (2003) and Chizema and Kim (2010) who indicate that the board should take a stronger role in strategy.

The input from board members, given their part-time status, is not equal. The empirical data generated in this study show that the involvement of board members in UK companies in strategy varies. Involvement in strategy is conditioned by board members interests, experience, past decisions taken, public pressure and corporate reputation, policies on corporate governance, company history and performance, risk preferences, informal relationships and ties with other board members, and established board processes. These influencers are discussed in the paper in order to explain the findings of this study as well as draw attention to the behavioural aspects of boards and the influence they have on strategy.

It is generally accepted that the board of directors is charged with overseeing and managing the affairs of the corporation whilst taking into account the best interests of the shareholder. Over a period of time the separation of corporate ownership from managerial control has become complete. Boards delegate to managers the day-to-day running of the organisation. In order to perform this task, managers are given the authority to make decisions that have varying levels of risk attached and they also have to consider appropriate responses to changes in the organisation's environment. As indicated by Count (2009), Boards and non-executives must spend more time understanding the risks in the business and 
need to be clear on what risk appetite the board is prepared to sanction to the chief executive and executives. Corporate boards are supposed to regularly monitor management's performance. There is an inherent danger where Chief Executive Officers and senior managers attempt to dominate their boards of directors and add board decision-making to their daily corporate decision-making. Such behaviour does not allow directors to fulfil their responsibilities. The OECD (2004) suggests that board members have three responsibilities. They should ensure the strategic guidance of the company, the effective monitoring of management by the board, and contribute to the board's accountability to the company and the shareholders.

Board members are generally chosen by senior management from the ranks of their recently retired senior executivesor from the pool of senior professional associates at other companies on the basis of personal ties or business relationships. It can also be the case that skilled board members are best found in those who already have experience in an industry. They are in essence at the top of the industry tree and so quite easy for those looking to fill boards vacancies to locate. Taking this approach the field becomes quite narrow. However, the learning curve is less steep and common experience helps to put discussion of issues in a familiar context. Such people may also lack the breadth of vision to be able to question long-held assumptions. They may take a 'minder' approach rather than make a useful and meaningful contribution to strategic advice and decision-making.

Following the Global Financial Crisis and a number of associated corporate collapses claims have been made that many boards of directors must have been "asleep at the wheel". Considerable concern and questions have been raised about the extent to which boards and their members can be expected to provide strategic guidance to the corporation's management. There is a lack of trust coming from a wide range of stakeholders and there are a range of events that have fuelled such a lack of trust. As Garratt states "As the world economies become weaker and the world's supply of capital decreases rapidly, the general public is becoming less trusting and more critical of board effectiveness - the performance and conformance of private and public sector corporations. Well-publicised cases of directoral fraud, incompetence, under-performance, cronyism, nepotism and opaqueness in decision-making have fuelled such public unease" (Garratt 1999, 29).

\section{Literature Review}

According to Garratt (1999) directing is seen as a reward at the end of a successful managerial or professional career. Millstein and MacAvoy (1998) agree with this view and indicate that board service has been largely viewed as an honorific position that responds to management's concerns and the supposed arm's-length relationship implied in the board's monitoring role over management is actually an often close collegial relationship between the two. Garratt (1999, p.29) indicates that directors should not be too vocal and should 'go with the flow'. He states that " They [directors] can be rewarded financially, have their pension funds filled with gold, their stock options increased, and be given whatever the cult motor car is appropriate for their status in their company. The only proviso seems to be that such "directors" do not rock the boat through intervening in the power politics between the chairman and chief executive".

In commenting on the selection of board members Monks and Minow (1991, p.76-79) indicate that "directors are not picked to challenge management" rather directors are selected on the basis that management are comfortable with those nominated and that they can work with them. A nomination committee usually undertakes the selection of directors for a corporate board; however, the process may not be as independent as it appears to outsiders. As Garratt (1999, p.30) states "Such nominal directors...seem to rub along in blissful ignorance of their accountabilities, liabilities and roles". For a board to be in there on the strategy front there needs to be a balance of skills and experience in the board as a whole. There is an inherent danger with a board entirely comprised of industry insiders as they can fail to grasp the full context of strategic issues for the corporation. Pettigrew and McNulty (1995) draw the distinction between minimalist boards that are created to minimise the impact of part-time board members, and maximalist boards where non-executives are drawn into 'shaping the content, context and conduct of strategy' with executives. Roberts (2002, p.246) indicates that "Work is done through creating the conditions under which the other non-executives can become effective". Board members need to understand the context in which they are operating in and fill in the gaps by supplying what is needed for the board to operate in a complementary and effective manner. As Roberts (2002, p.497) states "Complementary board processes seek to remedy through relationships the 'deficiencies' that each individual brings to their work. The 'perfect' board is the synergistic outcome of skilled board composition and effectively managed processes of board accountability". Roberts (2002) contrasts the 'perfect' board where its members are complementary to each other to what often occurs on boards, that is, the negative impact of complimentary relationships where behaviour is primarily a range of ceremonial acts and empty rituals that act to reinforce the status quo.

It has been long realised that not only is there an apparent flaw in the appointment of board members but there is a further weakness caused by lack of understanding of actual board activity (see Lorsch and MacIver (1989) and Mace 
(1971). Mace describes the disconnection between board responsibility and actual board activity: "Boards of directors of most companies do not establish objectives, strategies and policies, however defined. They do not ask discerning questions and they do not select the CEO" (Mace 1971, 185-186, 188). Mace's (1971) study found that boards did not perform the roles that are generally attributed to them. In fact, very little watching and monitoring was being conducted. However, in the last 5-10 years key stakeholders such as shareholders, institutional investors, investor lobby-groups and government agencies have exerted increased pressure on boards of directors of large corporations to take a more active interest in the companies whose boards they sit on. The evidence is mixed as to whether corporate boards are attempting to redress their passivity and dependence by becoming more active in the provision of strategic guidance to management. According to Grant Thornton's seventh annual Corporate Governance Review of the UK's FTSE 350,55 companies listed in the FTSE 350 still fail to identify at least one person on the audit committee who has recent and relevant financial experience". If chairmen and their board colleagues are not sufficiently experienced in the necessary accounting standards and practices then they are ill-equipped to provide any challenge to the work of their finance teams and their auditors. Additionally, their ability to contribute strategic advice and direction is severely limited. As stated by Lowe (2008) "In these times of uncertainty, it is crucial for the UK's leading companies to reassess their attitude and commitment to governance practices in order to retain the confidence of investors and other stakeholders, both in themselves and in London as "a global financial centre"".

The introduction of legislation and regulation has had mixed responses from corporations and their boards. Whilst many corporations are including more information in their annual reports and announcements to regulatory authorities, there does not appear to be any evidence that increased regulation correlates with increased interest and vigorous involvement in strategy by boards.

The responses from the UK have not been prescriptive and legislative, like the U.S. and the introduction of Sarbanes-Oxley Act of 2002 (also referred to as SOX) but rather the corporate collapses and scandals there have led the way to a new form of regulation the 'comply or explain' approach. The defining aspect of this approach is a voluntary code of best practice characterised by shareholder pressure for adoption. In particular, it is mandatory for companies to state in their annual reports whether they comply with the code and to identify and give reasons for any areas of non-compliance in light of their own particular circumstances. In short, the approach can be described as voluntary compliance coupled with mandatory disclosure. (For a fuller discussion see Pass, 2004)

The late Sir Derek Higgs commented that "Companies adhere more to the letter than the spirit of corporate governance...that can create significant problems and contribute to failure. They [companies] are regulated these days to within an inch of their lives, but the evidence suggests that boards' overwhelming focus on their backward-looking monitoring role gives them little time to cast more than a glance into the future. The penalties of the retrospective box-ticking approach are exemplified in a number of high-profile casualties, where the NEDs appeared to simply fall in with the CEO's increasingly high-risk strategy". (Arcot and Bruno, 2006)

The aim of regulation is to ensure good governance, however ensuring a balance between good corporate governance and effective strategy is essential for sustained business results. Whilst such balance is recognised by many boards, their evolution of boards from managerial rubber-stamps to active and independent monitors is yet to begin in some corporations. If we refer to the 2008 Corporate Governance Review on the UK's FTSE 350 we see that progress has been made by companies, although it has been slow, to ensure that there is at least one person on the audit committees with recent and relevant financial experience. However, now more than ever in the wake of the Global Finance Crisis, there has been increased pressure from stakeholders to stem the flow of corporate disasters; for directors to be alert, proactive and responsible; and a wish to avoid further serious performance problems associated with managerial entrenchment.

More is known about the structure and composition of boards than about boardroom behaviour and the dynamics that occur between board members. Hill (1995) sees that the role of board members and the organizational sociology of boards are an important, missing link in the analyses of corporate boards and board members. Our lack of knowledge about the work and conduct of boards and board members has been largely attributed to inadequate access to the corporate elite (Pettigrew and McNulty (1995). According to Leblanc and Schwartz (2007) "A major impediment for corporate governance researchers is simply that boards of directors are quite difficult to study directly. This problem is not a recent one." Additionally Zahra and Pearce note the difficulty of studying board process and they state:

"Overall, the relatively low number of empirical investigations into board process is explained in part by the difficulty in securing access to boards to observe process over time. Without such information, it will continue to be difficult to prescribe changes in the process by which boards should perform their roles. This is, in fact, one of the most challenging areas 
for future research in the contribution of boards". (1989, p.324)

Daily et al. (2003, 379), in their review of corporate governance research note the barriers and difficulties in acquiring access to boards of directors due to the potential for legal exposure. They state:

Directors' reticence to invite researchers into the "black box" of boardroom deliberations is understandable. The increase in shareholder activism has been accompanied by an increase in shareholder lawsuits in recent years. . D Directors fear that opening up boardroom activity to external scrutiny may also increase their risk of being subject to a shareholder lawsuit.

Such fear is reasonable given recent calls for directors and their action, or more often perceived inaction, to be placed under the spotlight and explained to shareholders and other stakeholders.

As Nowicki (2008, p.695) comments on recent scandals, "At best, these boards were poorly overseeing their corporations. At worst, the directors of these boards were wholly asleep at the wheel. ... Some corporate boards appear plagued by inattention, and some directors are asleep at the wheel".

Directors are viewed as highly accomplished individuals whose day to day activities are rarely subjected to the gaze from those outside the boardroom. As Garratt (1997) suggests that given that many directors are not trained to direct they have fears that assessment [and the gaze and scrutiny from those outside the boardroom] will find them lacking in some areas.

To let those outside the boardroom into the 'Black box' may cause discomfort to arise. The discomfort may arise according to Kazanjian (2000, p.47) "from boards realising that they may be opening a Pandora's box revealing sensitive issues such as under-performing or incompetent directors who may be a part of a coalition within the board who exert their will in order to meet their own needs rather than that of the corporation and its shareholders, for example. Once uncovered, such issues hitherto hidden, can no longer be ignored".

Additionally, we need only refer to when Bank of America stock plunged more than 75 percent in the first quarter of 2009 after CEO Ken Lewis engineered the disastrous acquisitions of Countrywide Financial and Merrill Lynch, while neglecting to tell regulators that Merrill paid $\$ 5.8$ billion in bonuses before the deal went through. Shareholders were livid and headlines posed the question "What were they [the board] thinking?" (Huffington Post August 19, 2008)

Indeed Psaros and Seamer (2002) are concerned that "anecdotal evidence and opinion dominate" and the danger inherent in making assumptions and then recommendations for change whilst relying on knowledge about the work and conduct of boards that is anecdotal. McNulty and Pettigrew (1999) recommend that "Normative models outlining the functions of boards and directors require greater empirical scrutiny. This is particularly true in relation to the role of boards and directors in company strategy". Whilst Goodstein et al. (1994) argues that boards should be active in strategy; there is inadequate treatment in the literature about boards and directors regarding their involvement in strategic decision-making. Finklestein and Hambrick (1996) have criticised what literature there is as being "descriptive and [providing] prescriptive strategy frameworks that omit attention to senior executives and board members".

Mace (1971), Herman (1981) and Lorsch and MacIver (1989) have carried out empirical studies about board behaviour but their conclusions are mixed and tend to indicate that boards have little if any involvement in strategy formulation. Lorsch and MacIver (1989) found in their research that boards focussed more on the advising and evaluating steps in the strategy formulation process than on initiating strategy. They concluded that most boards were relatively powerless. The data generated by Lorsch and MacIver (1989) revealed that boards were hindered by a number of critical weaknesses. Most directors were found to be discouraged from openly challenging or questioning the CEO's performance by the norms of polite boardroom behaviour and the pervasive presence of insiders. Directors also had a strong dependence on the CEO, as they possessed far greater information and knowledge about the business than any director could possess. The CEO rather than board members largely controlled the agenda of meetings and the discussion process. Finally, as the $\mathrm{CEO}$ often played a key role in the selection and appointment of directors, their continuing service on the board was dependent on their relationship to and in support of the CEO.

According to Sonnenfeld (2002) "What brings boards and companies down is not tangible, visible or measurable, it is dysfunction within their social system. The key isn't structural it's social. What distinguishes boardrooms that work is that their boards have robust, effective social systems with a virtuous cycle of respect, trust and candour."

Therefore, what is important rather than the discussion that has occurred on what boards of directors should be doing, that is, the tasks that they ought to be accomplishing - what appears to be missing is knowledge about the extent that boards are accomplishing these tasks by strategic involvement.

In today's turbulent and complex socio-economic environment organisations need to constantly adapt to a changing 
environment to survive. (Wood, Zeffane, Fromholtz, Weisner, and Creed, 2010). Power and control are no longer the paths to success in an organisation. Innovation and flexibility need to be infused into organisation practices. Pettigrew and Whipp (1991) indicate that the survival and competitive performance of an organisation is tied to a organisation's capacity to deliver change. Therefore, as indicated by McNulty and Pettigrew (1999), investigation should focus on whether board members attempt to influence the choices of organisations about corporate goals and the means to achieve them, and whether board members also seek to shape the change processes which realise those means and goals.

Agency theory nominates control as a principal role of boards. In addition, there are stakeholder expectations that boards should monitor the actions of agents (managers) on behalf of their principals (shareholders) (Eisenhardt, 1989; Fama and Jensen, 1983). Operationally boards monitor and evaluate an organisation's performance, its CEO and its strategies in order to fulfil their obligations of maximising shareholder wealth and minimising agency cost. In fact, Weisbach has described a board of directors as "the shareholders' first line of defence against incompetent management" (1988, p.431). Sometimes boards do fulfil these expectations and are in fact vigilant and exercise significant influence on the organisations they oversee (Kosnik, 1987). However, it cannot be assumed that all boards feel the same level of obligation to be vigilant. Whilst change must necessarily occur in response to changes in the organisation's internal and external environments, there are a range of risks associated with each change. The board's motivation to step up, consider and fully comprehend the range of risks associated with their actions varies significantly from one board to the next. Each foreseeable risk needs to be fully considered by the board and directors need to challenge and support each other in order to engage in the necessary foresight and visioning in order to consider unforeseeable risks. Johnson, Hoskisson and Hitt (1993) indicate that a vigilant board tends to be composed of a large group of independent, outside directors - individuals not otherwise affiliated with the corporation on whose board they sit. They also often own sizeable portions of the corporation's stock. Outside directors are seen as more vigilant than directors with other firm affiliations because they focus on financial performance, which is a central component of monitoring (Fama and Jensen, 1983; Johnson et al., 1993). They are more likely than insiders to dismiss CEOs following poor performance (Weisbach, 1988) and protecting their personal reputations as directors provides an important incentive to monitor and "keep their eye on the ball" (Fama and Jensen, 1983). Therefore, agency theory suggests that boards have substantial motivation and incentive to monitor CEOs and be active in initiating strategy as well as strategy formulation.

Yet change is important for most organisations. Radical change that results in a major make-over of the organisation and/or its component systems may be necessary when there is a critical event such as a merger or takeover or a dramatic failure in operating results. When such events occur the board must be prepared to recommend and support change and innovation rather than take the line of least resistance and choose inaction or lack of proactive behaviour.

The analysis of board members' involvement in the processes of influencing choice and change and the exercise of control are at the centre of the empirical contribution of this paper. The key question focuses on the extent board members are able to exert influence over the strategic decision-making and decision processes of the organisation, the power resources that are used, and the strategies and tactics that are brought to bear.

Although agency theorists emphasize the board's role as an independent control mechanism, Demb and Neubauer (1992) and Lorsch and MacIver (1989) suggest there is a second possible role for directors; to provide ongoing advice to top managers on possible strategic changes or the implementation of existing strategies In such cases, boards serve as a strategic consultant to top managers, rather than (or in addition to) exercising independent control. Pfeffer and Salancik (1978, p.170) believe that the provision of advice and counsel and the exercise of control are the two primary components of a board's internal administrative function. Roberts, McNulty and Stiles (2005) indicate that the work of non-executive directors goes beyond agency conceptions. Being a non-executive director and contributing to the strategy of the company is about accountability, about fulfilling the duties of a board member, and being prepared to question the status quo when necessary.

In other literature on boards and governance Mace (1971) and Wade, O'Reilly, and Chandratat (1990) suggest that there is considerable variance in the degree to which directors make an actual impact on strategic decision making, with some boards unable to monitor or advise management effectively. The board's ability to influence strategy may be affected by their lack of formal or social independence from management, as indicated by the percentage of outside or non-executive directors, the prevalence of friendship ties or other social connections between managers and directors, the lack of suitable knowledge or information to contribute meaningfully to strategy, an inability to devote the necessary time and attention as a result of serving on boards at multiple companies (Baliga, Moyer, and Rao, 1996; Boeker and Goodstein, 1993; Hill and Snell, 1988; Kesner, Victor, and Lamont, 1986; Mallette and Fowler, 1992; Wade et al., 1990). 


\section{Methodology}

Finklestein and Hambrick (1996) in their review of articles published on strategic leadership and boards of directors, noticed an increase in the use of archival data and concluded that many of the studies experienced difficulty in obtaining primary data. The absence of primary data is seen as a result of the difficulty in gaining access to this managerial elite (Leblanc and Schwartz, 2007, Daily et al. 2003, Pettigrew, 1995). With these issues in mind the research methodology was designed to overcome these key problems by being acutely aware of board members' concerns about confidentiality and legal issues and the use of multiple methods of data collection.

Respondents were assured of confidentiality. Although the individual companies involved in the study are identified, respondents are not. Board members expressed their views of their world rather than speaking on behalf of the corporation or purporting to represent the views of the board as a whole or indeed the corporation. Respondents were encouraged to "make sense" (Weick, 1995; Weick, 2001) of their behaviour as a board member and to examine their involvement in strategy in terms of "taking strategic decisions", "shaping strategic decisions" and "shaping the context and conduct of strategy". Each of these three levels of involvement in strategy engages board members in processes of choice, change and control in different ways (McNulty and Pettigrew, 1999). A model based on this rationale, developed by McNulty and Pettigrew (1999) has been adapted for use in this research conducted with board members of UK corporations.

\section{$<$ Table 1 about here $>$}

\subsection{Respondent Selection}

In order to identify the company boards to include in the study the researcher used the FTSE 100.

The researcher used personal relationships and networks in the attempt to negotiate access to directors in each of the companies selected. Interviews and secondary data were conducted over a six-month period. Interviews lasted from between 30 minutes and 45 minutes. An undertaking of confidentiality and non-disclosure of the respondent's identity was given in each case. The interviews that were obtained were supplemented by public statements issued by board members to the press, public statements made by senior management and board members at shareholders meetings, newspaper, journal, television and radio interviews with senior management and board members, internal corporate documentation, and company annual reports. The central themes of the interviews and secondary data for 30 board members were extracted and the results are reported and discussed. After preliminary contact with board members within the researcher's personal network and investigation of the matching secondary sources of data on the board member and their company, a decision was made to focus on where there was most data to be gathered. The intent of this study was firstly, to gather empirical data to gain insights into the involvement of board members in UK companies in strategy. A second aim was to highlight the factors that influence involvement in strategy and draw attention to the behavioural aspects of boards and the influence they have on strategy. It was not the intent of this study to provide any universal truths or recipes about boards and involvement in strategy.

The board members for this study were drawn from Astra Zeneca, BP, BHP Billiton, Marks and Spencer, Tesco, Vodafone, Lloyds TSB. Their views were compared with those of board members from companies outside the FTSE 100 who were drawn from Alstrom, Corus, and Tata Steel, and the services companies Hansen Green, and Bradford and Bingley.

\section{Results}

Comments were quite revealing. It is interesting that many respondents had not previously taken the opportunity to reflect on their actions and consider the types of contributions they made in the boardroom. Critical examination and reflection of past behaviour and decisions is a necessary underpinning for individual growth and development as well as for companies and organisations to learn, correct mistakes and formulate a strategic future.

The themes that emerged in the 2006 study by the author were again used to guide the analysis and reporting of the results of this study. Whilst the themes from the previous study were used as a guide, new themes were also considered and are reported.

Board members discussed the many ways in which directors interact and behave as they fulfil their duties. From these discussions a picture of board processes and how to execute them became clear.

The ability of a board of directors to do all the things scholars and corporate governance experts advocate depends on the quality of the individuals who become directors and their ability to get the work of the board done as a group. The insight that boards are groups, and hence that such group processes as conflict, teamwork, and comprehensiveness are critical determinants of board effectiveness, opens up a new path on how to improve board effectiveness. Rather than 
simple counts of insiders and outsiders, a focus on board process suggests that the nature of the interactions among board members influences their effectiveness in fulfilling the key roles of advice and counsel for, and monitoring of, CEOs. (Charan, 1998; Forbes and Milliken, 1999; Sonnenfeld, 2002)

How much of a contribution to strategy a board makes to some extent depends on the experience, skill and judgements of individual executive and non-executive directors and the ways in which they combine. The dynamics in a board are incredibly important. Forbes and Milliken (1999), Sundaramurthy and Lewis (2003), and Roberts et al. (2005) suggest that the effectiveness of boards depends on the level of social interaction between the members and the exchange of information and critical discussion. There is a need to exert control but also for collaboration between the board and management.

Each director in this study mentioned that board members have different experiences and were bound to have different views therefore the potential for conflict was inevitable. Sixty percent $(60 \%)$ of directors flagged the importance of constructive conflict, which occurs when directors hold and debate diverse views among themselves and with the CEO. These exchanges of views assist the board to have a better understanding of the issues that surround the decision context. It is then possible to synthesize and distil the multiple points of view into a decision that is often superior to any individual view. As with other groups, constructive conflict improves decision-making in a board and is an important determinant of effectiveness (Amason, 1996; Jehn, 1995).

Conflict in decision-making was seen as constructive by one board member who stated:

"Because of recent events and circumstances, the role of NEDs has grown appreciably. I don't entirely share the view increasingly held that more powerful non-executives are needed to keep a check on executives, but certainly the role they play will be that much more important and assertive. Like all appointments, it's always the quality of the individual that counts".

Another board member added:

"Part of the problem is that it is easy for a board to concentrate on process rather than rethink well-oiled procedures. It doesn't really matter where NEDs come from, so long as they have a questioning mind and are able to think outside the box".

Board members often experience pressure to conform to the dominant view and group think sets in (see Janis 1972). There are quite complex sets of relationships that need to be regularly attended to and reinforced in terms of boardroom power plays and politics. However, many board members indicated that boards should not operate to "tie the hands" of those who must follow their conscience. Boardroom pressure cannot be seen to be an excuse for corporate mismanagement or misbehaviour.

This view is best expressed by a board member who stated that;

"In my experience as a non-executive director, the biggest problem is overwhelming consensus and conformity. In particular 'non-executive directors' who acquiesce to the executives on the ground that 'they know best' and because they don't want to scupper their position. That reinforces 'in-box' thinking and discourages innovation."

A further board member states;

"As I see it...the important issue is whether or not the board is able to have the conversations that it needs in different areas. Havoc is wrecked by boards' inability or unwillingness to address key issues."

Constructive conflict can pit one director's views against another's, and while open discussion has clear value, sometimes such task-oriented, constructive debates are taken more personally. For example, board members who are not used to being confronted as an ordinary course of business might feel threatened when other directors challenge their ideas. When personal and emotional considerations gain prominence, constructive conflict spirals into destructive conflict, degrading group decision-making and interfering with the board's ability to perform its key roles (Amason, 1996; Jehn, 1995).

Many topics may create division in the board particularly where some proposals and decisions challenge board members sets of values and beliefs. However based on an argument of values and beliefs some board members attempt to shape decision outcomes by the use of politically shaped agendas. As expressed by a board member;

"It's hard to get at the critical issues that can trigger division...Its very difficult to uncover 
the hidden agendas, the 'undiscussables'. It's about managing the personal dynamics and there is a level of challenge that exists in that".

One board member, whilst acknowledging that boardroom politics can stifle dissenting views, indicated how boards should operate. It was stated that;

"A strong chairman of an engaged and normally united board might be able to manage dissent. But sometimes they need to act decisively and get rid of someone. Desperate attempts to find a compromise can come back and bite you."

Another board member reinforces this point, whilst highlighting that conflict does not only arise based on the strength of the chairman, but rather individuals' personalities and their motives. He states;

"Most boardroom disputes arise because of ego...it is individuals who cause difficult situations, and some situations are just impossible to manage. If there is a fundamental and irreconcilable disagreement on the board, someone has to go. Otherwise resentment will bubble."

Teamwork is seen as important to the board process and it was mentioned by ninety percent $(90 \%)$ of board members in this study. Since board members, like top management teams, are confronted with complex and ambiguous strategic decisions, they too are required to work together by sharing information, resources, and decisions (Hambrick, 1994; Hambrick, 1998; Siegel and Hambrick, 1996; Hambrick, 2007). Boards that are unable to work as a team end up less able to rein in and control powerful CEOs. Without a team approach boards are also likely to be less effective at providing the advice and counsel at which more collaborative boards excel.

Recent corporate failures and incidences of mismanagement in companies such as Northern Rock and Equitable Life and the associated public arguments and blaming of each other divides board members and provides evidence that boards often do not act like teams. The development of strong team norms can be challenging because boards meet at best on a monthly basis and, hence, have few opportunities to coalesce as a group. The importance of working together in a team has been stressed in the top management team literature. (Hambrick, 1994; Hambrick, 1998; Siegel and Hambrick, 1996; Hambrick, 2007).

This view was supported by a number of board members. One board member emphasises that effective boards need aculture of cooperation. They state;

"NEDs should fly higher than ground level and at an appropriate altitude to be able to see the bigger picture and ask the obvious questions. ... It is also important that the board encourages a culture where asking the simple questions will be accepted as good common sense."

But as one board member emphases a culture of cooperation is not always present. In fact the danger of division is often present. They stated:

"You often hear the executives saying 'let's keep the non-execs away from this because they won't understand it'. But they fail to appreciate the role that non-execs should be playing, and often interpret it as being to put the brakes on them."

A further board member enlarged on this point saying;

"The key qualities a non-exec needs are curiosity, courage, the right chemistry for the corporate culture and the competence and confidence to challenge complicated issues. But it is difficult to exercise those in a corporate culture that is not receptive to it".

Another board member referred to "when you are the lone duck on the water'. He stated;

"If you are from retail or an engineering background, for example, and you are surrounded by sharp, big-time banking executives and a very experienced banker as chairman, it takes a lot of courage to challenge them and say this doesn't feel right."

It is possible to have expertise that can save the board from possibly making errors of judgement, however, unless you are a strong person prepared to 'stand up for what you believe is right' then in essence as a board member you are deciding to not to make a decision that contributes to strategy.

All boards have some level of involvement in major strategic decisions. The level of involvement by boards in issues and decisions differs significantly. All boards included in this study were involved in taking strategic decisions, that is, where influence is exerted inside the boardroom and the board takes decisions to either accept, reject, or refer proposals. 
No board members saw their role as rubber-stamping, or at least none admitted to that view. However, $35 \%$ of board members referred to the 'balancing act' that they need to perform by providing enough assistance and advice and asking 'appropriate' questions without encroaching on 'the territory of management'.

This view is expressed by a board member who suggests that board members should know their place, that is, contribute advice but 'not cross the imaginary line in the sand' and be too 'hands on'. They stated;

"The role that independent directors play is critical, but very difficult, given the need for them to engage with the business effectively without straying into day-to-day management."

Some board members view their role in slightly narrower and more cautious terms.

"In my view, non-executives shouldn't tinker with details. They should ask obvious questions, and not be concerned with putting their foot in it. NEDs should put being respected above being liked and always give assistance in wanting to support the company to be more successful in the long term. These are the issues that should be in the front of the mind for a non-executive. I mean you can't go in there swash-buckling and waving your sword around"

There are clearly some differences of opinion as to the role of non-executive directors. These differences appear to be fuelled by recent scandals and mismanagement that mainly occurred in the U.S. (Enron, Worldcom, Arthur Andersen, Lehman Brothers, and Bank of America to name just a few). In fact the scandals and the fall out from the Global Financial Crisis have had a significant impact on organisations around the world - "the cat has been put among the pigeons."

This concept is expressed by a board member;

"Recent economic issues have put the spotlight on the performance of both executives and non-executives. At board level there has to be accountability of how business performs, and it is important that in the turmoil that exists we do not forget to reflect on how things happened and what lessons can be learned."

Many non-executives are concerned to be 'doing their jobs' as there have been a number of threats of legal action against boards both in the U.S., the U.K., and in Australia by shareholder groups and government regulators.

This is well expressed by a board member who stated;

"With the increases in corporate governance, you get non-executives who see their role primarily as challenger and checker to the executives, whereas the executives believe they should behave as more collegiate members of the board. That situation could be avoided if the company was more explicit about the requirements and expectations of people carrying out different roles."

Some board members recognise that there may be other interests that are being catered for, other than the 'best interests of the company'. One board member indicated;

"In a very aggressive stock market you are only as good as your last quarterly results, and that puts huge pressure on executives to keep delivering against very short-term criteria. Chief executives no longer have the luxury of being able to take a three-to-five-year view, and are impatient for success. This, some believe, makes them more self-interested and self-serving, rather than having their companies' best interests at heart."

This board member highlights the point that differences in views about the role of the board, in particular non-executive directors, in strategy may have more to do with politics and the exercise of power rather than role clarity.

"There is also a possible mismatch in expectations between the two sides. Executives say they wish the non-execs would engage more, while non-executives say they wish the executives would make more use of them. This discord is frequently interpreted as individuals playing politics".

Whilst some board members are prepared be more involved in strategy, others see their role as that of "review and reaction". As one board member indicated;

"Non-executive directors, must stand united, follow procedure, sing from the same hymn sheet, and always make it plain that what they do, they do for the shareholders."

The accepting, rejecting or referring of proposals for further clarification is the taking of a strategic decision and is seen 
as the minimum acceptable level of board involvement. Involvement at this level of strategy has been referred to as acting as a "monitoring device" and "corporate watch-dog".

Board members did not discount the importance of monitoring and disciplining as such roles allowed the board to align $\mathrm{CEO}$ and shareholder interests. Many board members attributed corporate problems and failures to not enough attention being paid to monitoring and that in the case of recent corporate disasters boards have stakeholders asking "what were they thinking?"

Several board members mentioned that it became difficult to meet their obligations and protect shareholders' interests when they did not have direct involvement, making them reliant on the CEO and executives for information to make decisions. This difficulty is highlighted by a board member who stated:

"The board is required to make decisions in the best interests of this company...so it is important for us to be well informed. It [the information given] needs to sufficiently detailed and clear."

Board members may have the intent of exercising greater involvement in strategy; however, their attempts can be frustrated by CEOs who dominate the chairman of the board to get their will catered to. Decision-making becomes shaped by power, politics, and the exercise of influence by the dominant coalition. Information can be given at a late stage where it makes it extremely difficult if not impossible to digest and critically analyse a large volume of data that has a high level of detail. In these circumstances the board goes through the motions and ratifies what the CEO has already determined as "the" decision.

As one board member stately clearly:

"The level of information a board needs depends on the issue at hand...but it's the quality of what is provided that is important. What often makes it difficult to contribute is when you are given too short a timeframe to review complicated matters and documentation. In essence you end up 'railroaded'."

Another board member reinforced this view by stating;

"A CEO to some extent can "steer the agenda". That is to say that the CEO can have information go out late so that it does not give directors must time to digest it and form a view."

In addition to exercises of power and cooptation, board members are acutely aware that the information they receive is "filtered" in terms of what information is conveyed to the board and what information is blocked. The selective release of information to the board is an exercise in shaping decisions and outcomes. Board members seemed well aware of the manipulations that often occurred to shape decisions.

However, some board members indicated that they were proactive when they suspected that a form of manipulation was occurring or had occurred. One board member stated;

"It is a director's responsibility to be informed...if your not happy with the information

provided questions should be raised prior to or at least at the meeting."

Forty three percent (43\%) of board members in this study indicated a deeper level of involvement where the board involves itself in the shaping of strategic decisions, that is, where influence occurs early in the decision process as board members shape the preparation of proposals by executives. Consultation with board members by the executive, either formally or informally, whilst a proposal is being prepared enables board members to test ideas, raise issues, question assumptions, advise caution, and offer encouragement. Executives 'test drive', 'see which way the wind is blowing' and 'horse trade' with elements and concepts of proposals in anticipation of the need for board approval.

Some twenty-one percent (21\%) of board members indicated that they were a member of a board involved in the deepest level of strategy involvement, that is, the board is involved in shaping the content, context and conduct of strategy. The board's influence is continuous and not confined to decision episodes and the board develops the context for strategic debate, establishes a methodology for strategic development, monitors strategy content, and alters the conduct of the executive in relation to strategy.

One board member indicated that:

"Non-executives are incredibly important to large corporations but even more so to SMEs

'small and medium enterprises' because they often make up for the lack of in house resources

in terms of governance expertise and other important in-depth sector experience. This is 
never more so that when the company is going through M \& As 'mergers and acquisitions'. They 'non-executive directors' need to be really committed. It's no long a matter of turning up for the occasional lunch."

All of the board members in this study mentioned that the level of effort required of board members had increased significantly over time. One board member stated:

"It takes longer than a three-hour monthly board meeting to understand the complex issues in a business such as banking, which is constantly changing. It requires a significant time commitment to keep abreast of regulations, not to mention the bank's own strategy, products and services."

Board members in this study emphasised that if a board deems a matter important and strategic enough to require their involvement, they must make the effort to address that decision comprehensively. The problem is that boards often limit their exploration of decision alternatives due to time and resource constraints and tend to "just do enough to get by". Factors affecting the level of decision comprehensiveness include the financial condition of the company and the potential risks that might emerge and whether there is an impending crisis. When the margin for error is small because of financial difficulties or competitive stresses, a wider search for options and greater scrutiny is called for (Fredrickson and Mitchell, 1984; Fredrickson, 1985).

There are a number of elements that contribute to decision comprehensiveness. Additional effort from board members needs to be focussed and incisive. Decisions need to be derived through unified effort with board members' contributions based on their areas of expertise. Effective decision making is based on mutual trust between board members as well as between the board and the CEO.

The board and the CEO should work together as a partnership in order to achieve the goals of the corporation through good decision-making.

A minority of boards in this study shapes the content, context and conduct of strategy, that is, the deepest level of involvement in strategy. These boards shape strategy by establishing a vision for the future and a set of underlying values. Boardrooms need to have strong sense of ethics and corporate social responsibility that underpins decisions. In order to achieve this board members need to be independent in their thinking, willing to put themselves on the line and take personal risks to defend their beliefs and values. They need to be willing to take significant principled action that may cause short-term problems rather than be rubber-stamping.

The issue of guiding values and the board's involvement in the conduct of strategy was exemplified by a board member's regarding overbearing chairmen and management executives:

"A few years ago there were bosses that were bullies who would not tolerate discussion, let alone disagreement with their views. But the separation of the roles of chief executive and chairman forced by UK corporate governance codes has changed that. And there are now more and better non-executives (NEDs). They are more powerful and have moderated that sort of behaviour... they wont tolerate having values compromised and being rail-roaded. Shareholders have more peace of mind."

It appears that it is not only a set of shared values that unifies members of a board and gives the appearance of a team approach to strategy. In addition it would appear that mutual concern for the protection of individual's reputations may be a reason why board members will go to the deepest level of involvement in strategy.

As indicated by one board member who stated:

"Reputation is important and you need to preserve it..."

Board members saw a link between risk to their reputations and the risk of failure for the organisation. It was stated by a board member that:

"If outside directors bring experience and strategic expertise, together with vigilance in monitoring management decisions, it is plausible that they will be effective in preventing strategic mistakes and opportunistic behavior by management."

Board members shape both ideas that form the content of strategy as well as the methodologies and processes through which those ideas evolve. In this study, board members indicated that they presented to their respective boards many of the methods of strategy development and formulation that they used in their previous roles of senior executives and CEOs of other companies. A board member whose previous role involved a number of mergers and acquisitions states: 
"Mergers and acquisitions will be more important to growth in the future. We [non-executive directors] will need to keep a close eye on that action. I've seen many acquisitions destroy value for the acquirer. The other thing we'll need to watch for is this current liquidity crisis and where the funds will come from.”

The scope of governance is a contested area, some commentators interpret it narrowly as referring to the maximisation of shareholder wealth, whereas, for others, governance has evolved to include corporate accountability, corporate social responsibility, risk management and the protection of interests of other stakeholders apart from shareholders.

The statements from board members highlight the deliberate rather than emergent nature of the strategies adopted when there is greater involvement in strategy through the shaping of the content, context and conduct of strategy. As strategic involvement increases board members progress to shape both the ideas that form the content of strategy as well as the methods and processes through which those ideas evolve (McNulty and Pettigrew, 1999).

The themes discussed above do not provide an exhaustive explanation of board members' involvement in strategy. They were informed by and build upon the findings of Kemp's (2006) study. The observations presented are those that the author believes offer the most promising line of enquiry for further research and have the greatest potential for building on existing models of board behaviour (Pettigrew and McNulty, 1995; McNulty and Pettigrew, 1999).

It is clear that board members' increased involvement in strategy is fuelled by a range of factors that include increased expectations from a range of stakeholders (such as shareholders, shareholder activist groups, institutional investors, employees, regulatory agencies), heightened public scrutiny and criticism of corporate failures and scandals, as well as concern about group and individual reputations. In their attempts to increase involvement in strategy, board members need to firstly be prepared to engage in constructive conflict; avoid destructive conflict; work together as a team; know the appropriate level of strategic involvement to pursue at a given time and in a given set of circumstances; and address decisions comprehensively (Kemp, 2006).

\section{Conclusion}

This paper has described and analysed the contribution to strategy made by board members in a selection of UK companies based on access and the volume of data available. A model of three levels of involvement in strategy developed by McNulty and Pettigrew (1999) was adapted and used as an guiding framework in Kemp's (2006) study and applied again in this study to explore strategic involvement, and the processes of strategic choice, the influencing of change and the exercise of power and control.

Similar to the Kemp (2006) study it was found that the input from board members is not equal. The empirical data generated in this study shows that the involvement of board members in UK companies in strategy varies. Involvement in strategy is conditioned by board members interests, experience, past decisions taken, public pressure and corporate reputation, preserving group and individual reputations, policies on corporate governance, company history and performance, informal relationships and ties with other board members, and established board processes. It was clear that stakeholder expectations, public pressure, or the introduction of legislation is likely to have little effect on increasing board members involvement in strategy. Rather, a board member's feelings of obligation and interest in being involved in shaping the content, context and conduct of strategy is a better indicator that they will pursue a deeper level of involvement in strategy.

To support a board member's efforts to pursue a deeper level of involvement in strategy, the board as a whole, need to be willing to engage in constructive conflict; avoid destructive conflict; work together as a team; know the appropriate level of strategic involvement to pursue at a given time and in a given set of circumstances; increasingly gain deeper knowledge of the corporation and its operations, use foresight and act proactively as opposed to being caught in reactive situations, and address decisions comprehensively (Kemp, 2006).

A process that board members can follow to exert a controlling influence over CEOs and executives so that they can be "in the driver's seat" and contribute to the overall strategic direction and outcomes of the corporation was presented in Kemp (2006) and re-established using UK data. It is recommended that the results and conclusions of this study should be tested by further research with a larger number of corporations in a wider range of industries in different international settings. 


\section{References}

Adams, M.A. (2002). The convergence of international corporate governance systems - Where is Australia heading? Keeping Good Companies, March, 78-83.

Amason, A. C. (1996). Distinguishing the effects of functional and dysfunctional conflict on strategic decision-making: Resolving a paradox for top management teams. Academy of Management Journal, 39(1), 123-148.

Arcot, S., and Bruno, V. (2006). In letter but not spirit: An analysis of corporate governance in the UK, SSRN working paper.

Bathula, H. (2008). Board characteristics and firm performance: Evidence from NZ, Unpublished PhD thesis, Auckland University of Technology.

Baysinger, B.D., and Hoskisson, R.E. (1990). The composition of boards of directors and strategic control: effects on corporate strategy, Academy of Management Review, 15, 72-87.

Carpenter, M., and Westphal, J. (2001). Strategic context of external network ties: Examining the impact of director appointments on board involvement in strategic decision-making, Academy of Management Journal, 44, 639-660.

Charan, R. (1998). Boards at work: How corporate boards create competitive advantage. San Francisco: Jossey-Bass.

Chizema, A., and Kim, J. (2010). Outside directors on Korean boards: Governance and institutions, Journal of Management Studies, 47, 109-129.

Conger, J.A., Lawler, E.E., and Finegold, D.L. (2001). Corporate boards: New strategies for adding value at the top. San Francisco: Jossey-Bass.

Conyon, M.J., Peck, S.I., and Sadler, G.V. (2001). Corporate tournaments and executive compensation: evidence from the U.K, Strategic Management Journal.

Daily, C. M., Dalton, D. R., and Cannella, A. A. (2003). Corporate governance: Decades of dialogue and data, Academy of Management Review, 28(3), 371-382.

Demb, A., and Neubauer, F. (1992). The corporate board. New York: Oxford University Press.

Dewally, M., and Peck, S. (2010) .Upheaval in the boardroom: Outside director public resignations, motivations and consequences, Journal of Corporate Finance, 16, 38-52.

Eisenhardt, K. (1989). Agency theory: An assessment and review, Academy of Management Review, 14, 57-74.

Fama, E., and Jensen, M. (1983). Separation of ownership and control, Journal of Law and Economics, 26 (June), 301-325.

Finkelstein, S., and Hambrick, D. (1996). Strategic leadership: Top executives and their effects on organisations. Minneapolis: West Publishing.

Forbes, D. P., and Milliken, F. J. (1999). Cognition and corporate governance: Understanding boards of directors as strategic decision-making groups, Academy of Management Review, 24(3) 489-505.

Fredrickson, J. (1985). Effects of decision motive and organizational performance level on strategic decision processes, Academy of Management Journal, 28(4), 821- 843.

Fredrickson, J., and Mitchell, T. (1984). Strategic decision processes: Comprehensiveness and performance in an industry with an unstable environment, Academy of Management Journal, 27(2), 399- 423.

Garratt, B. (1999). Developing effective directors and building dynamic boards, Long Range Planning, 32 (1), 28-35.

Goodstein, J., Gautum, K., and Boeker, W. (1994). The effects of board size and diversity on strategic change, Strategic Management Journal, 15, 241-250.

Grant Thornton, (2009). FTSE 350 corporate governance review, London: Grant Thornton Risk Management Services.

Hambrick, D. C. (1994). Top management groups: A conceptual integration and reconsideration of the 'team' label. In Research in Organizational Behavior, Staw, B. M., \& Cummings, L. L. (Eds.). Greenwich, CT: JAI Press: 171-214.

Hambrick, D. C. (1998). Corporate coherence and the top management team. In Hambrick, D. C., Nadler, D. A., and Tushman, M. L. (Eds.) Navigating change: How CEOs, top teams, and boards steer transformation. Boston, MA: Harvard Business School Press: 123-140.

Hambrick, D.C. (2007). Upper echelons theory-An update, Academy of Management Review, 32(2), 334-343. 
Hendry, K., and Kiel, G.C. (2004). The role of the board in firm strategy: Integrating agency and organizational control perspectives, Corporate Governance: An International Review, 12(4), 500-520.

Herman, E. (1981). Corporate control, corporate power. New York: Cambridge University Press.

Higgs, D. (2003). Review of the role and effectiveness of non-executive directors. London: DTI.

Hill, S. (1995). The social organisation of boards and directors, British Journal of Sociology, 46(2), 245-278.

Huse, M. (2003). Renewing management and governance: New paradigms of governance, Journal of Management and Governance, 7(3), 211-221.

Huse, M. (2005). Accountability and creating accountability:A framework for exploring behavioural aspects of corporate governance, British Journal of Management, 16, s65-80.

Ingley, C., and $\mathrm{Wu}, \mathrm{M}$. (2007). The board and strategic change: A learning organisation perspective, International Review of Business Research Papers, 3(1), 125-146.

Janis, I. (1972). Victims of groupthink: A psychological study of foreign-policy decisions and fiascoes. Oxford, England: Houghton Mifflin.

Jehn, K. A. (1995). A multi-method examination of the benefits and detriments of intragroup conflict, Administrative Science Quarterly, 40(2), 256-283.

Johnson, R., Hoskisson, R., and Hitt, M. (1994). Downscoping: How to tame the diversified firm. New York: Oxford University Press.

Kemp, S. (2006). In the driver's seat or rubber stamp? The role of the board in providing strategic guidance in Australian boardrooms, Management Decision, 44 (1), 56-73.

Kiel, G., and Nicholson, G. (2003). Boards that work, North Ryde: McGraw-Hill.

Kosnik, R. (1987). Greenmail: A study of board performance in corporate governance, Administrative Science Quarterly, 32, 163-185.

Langevoort, D.C. (2000-2001). The human nature of boards: Law, norms and the unintended consequences of independence and accountability, Georgetown Law Journal, 89, 797.

Leblanc, R., and Schwartz, M. (2007). The black box of board process: Gaining access to a difficult subject, Corporate Governance: An International Review, (September), 843-851.

Long, T., Dulewicz, V., and Gay, K. (2005). The role of the non-executive director: Findings of an empirical investigation into the differences between listed and unlisted UK boards, Corporate Governance, 13, 667-679.

Lorsch, J., and MacIver, E. (1989). Pawns or potentates. Boston: Harvard Business School Press.

Mace, M. (1971). Directors: Myth and reality. Cambridge, MA: Harvard University Press.

McNulty, T., and Pettigrew. A. (1996). The contribution, power and influence of part-time board members, Corporate Governance: An International Review, 4(3), 160-179.

McNulty, T., and Pettigrew. A. (1999). Strategists on the board, Organisational Studies, 20(1), 47-74.

McNulty, T., Roberts, J., and Stiles, P. (2005). Undertaking governance reform and research: further reflections on the Higgs review, British Journal of Management, 16(Special Issue), S99-S107.

Millstein, I.M., and MacAvoy, P.W. (1998). The active board of directors and performance of the large publicly traded corporation, Columbia Law Review, June, 1283-1322.

Monks, R.A.G., and Minow, N. (1991). Power and accountability New York: HarperBusiness., 76-79.

Monks, R.A.G., and Minow, N. (1996). Watching the watchers: corporate governance in the 21st century, New York: Blackwell.

Nowicki, E. A. (2008). Director intention and director protection under Delaware general law section 102 (b) (7): A proposal for legislative reform, Delaware Journal of Corporate Law, 33, 695.

Organisation for Economic Cooperation and Development (2004). OECD Principles of Corporate Governance. Paris: OECD Publications.

Oliver, R., (2000). The board's role: Drivers seat or rubber stamp, Journal of Business Strategy, 21, 7-8.

Pass, C. (2004). Corporate governance and the role of non-executive directors in large UK companies: An empirical 
study, Corporate Governance, 4, 52-63.

Pettigrew, A. (1992). On studying managerial elites, Strategic Management Journal, 13, 163-182.

Pettigrew, A., and Whipp, R. (1991). Managing change for competitive success, Oxford: Blackwell.

Pettigrew, A., and McNulty, T. (1995). Power and influence in and around the boardroom, Human Relations, 48(8), 845-873.

Pfeffer, J. (1972). Size and composition of corporate boards of directors: The organisation and its environment. Administrative Science Quarterly, 17, 218-228.

Pfeffer, J., and Salancik, G.R. (1978). The external control of organisations: A resource dependence perspective, New York: Harper and Row.

Pound, J. (1995). The promise of the governed corporation, Harvard Business Review, 73, 89-98.

Psaros, J., and Seamer, M. (2002). Horwath 2002 Corporate Governance Report, Sydney: Horwath Pty Ltd.

Pye, A. (2001). A study in studying corporate boards over time: Looking backwards to move forwards, British Journal of Management, 12, 33-45.

Pye, A., and Pettigrew, A. (2005). Studying board context, process and dynamics: Some challenges for the future, British Journal of Management, 16, S27-38.

Roberts, J. (2002). Building the complementary board: The work of the Plc chairman, Long Range Planning, 35, 493-520.

Roberts, J., McNulty, T., and Stiles, P. (2005). Beyond agency conceptions of the work of the non-executive director: creating accountability in the boardroom, British Journal of Management, 16(Special Issue), S5-S26.

Siegel, P. A., and Hambrick, D. C. (1996). Business strategy and the social psychology of top management teams. In Shrivastava, P., Huff, A., \& Dutton, J. (Eds.). Advances in Strategic Management, 3. Greenwich, CT: JAI Press, 91-119.

Sonnenfeld, J. (2002). What makes great boards great, Harvard Business Review, 80(9), 106-113.

Stiles, P. (2001). The impact of the board on strategy: An empirical examination, Journal of Management Studies, 38, 627-650.

Van der Walt, N.T., and Ingley, C.B. (2001). Evaluating board effectiveness: The changing context of strategic governance, Journal of Change Management, 1(4), 313-331.

Wade, J., O'Reilly, C.A., and Chandratat, I. (1990). Golden parachutes: CEOs and the exercise of social influence, Administrative Science Quarterly, 35, 587-603.

Weick, K.E. (1995). Sensemaking in Organization. London: Sage.

Weick, K.E. (2001). Making Sense of the Organization. Oxford, UK: Blackwell.

Weir, C., and Lain, D. (2001). Governance structures, director independence and corporate performance in the UK, European Business Review, 13 (2), 86-94.

Weisbach, M.S. (1988). Outside Directors and CEO Turnover, Journal of Financial Economics, 20(Jan/Mar), 431-460.

Westphal, J. (1999). Collaboration in the boardroom: Behavioral and performance consequences of CEO-board social ties, Academy of Management Journal, 42, 7-24.

Wood, J., Zeffane, R., Fromholtz, M., Wiesner, R., and Creed, A. (2010). Organisational behaviour: Core concepts and applications. Brisbane: John Wiley and Sons Australia.

Zahra, S. A., and Pearce II, J. A. (1989). Boards of directors and corporate financial performance, Journal of Management, 15(2), 291-334.

\section{Notes}

Note 1. This paper draws and builds on the study reported in Kemp, S. (2006). In the driver's seat or rubber stamp?: The role of the board in providing strategic guidance in Australian boardrooms, Management Decision, 44 (1), 56-73. 
Table 1. Levels of Board Member Involvement in Strategy

\begin{tabular}{|c|c|c|c|}
\hline & Taking Strategic Decisions & Shaping Strategic Decisions & $\begin{array}{c}\text { Shaping the Content, } \\
\text { Context and Conduct of } \\
\text { Strategy }\end{array}$ \\
\hline Definition & $\begin{array}{l}\text { Influence is exerted inside } \\
\text { the boardroom }\end{array}$ & $\begin{array}{l}\text { Influence occurs early in the } \\
\text { decision process as board } \\
\text { members shape the preparation } \\
\text { of proposals by executives }\end{array}$ & $\begin{array}{c}\text { Influence is continuous and } \\
\text { not confined to decision } \\
\text { episodes }\end{array}$ \\
\hline Board Behaviour & $\begin{array}{l}\text { Inside the boardroom, board } \\
\text { take decisions to either } \\
\text { accept, reject or refer } \\
\text { proposals }\end{array}$ & $\begin{array}{l}\text { Consultation with board } \\
\text { members by the executive, } \\
\text { either formally or informally, } \\
\text { whilst a proposal is being } \\
\text { prepared enables board } \\
\text { members to test ideas, raise } \\
\text { issues, question assumptions, } \\
\text { advise caution, and offer } \\
\text { encouragement. } \\
\text { Executives 'test drive', 'see } \\
\text { which way the wind is blowing' } \\
\text { and 'horse trade' with elements } \\
\text { and concepts of proposals in } \\
\text { anticipation of the need for } \\
\text { board approval. }\end{array}$ & $\begin{array}{l}\text { The board develops the } \\
\text { context for strategic debate, } \\
\text { establishes a methodology } \\
\text { for strategic development, } \\
\text { monitors strategy content } \\
\text { and alters the conduct of the } \\
\text { executive in relation to } \\
\text { strategy }\end{array}$ \\
\hline $\begin{array}{c}\text { Strategic } \\
\text { Involvement }\end{array}$ & $\begin{array}{l}\text { All boards take strategic } \\
\text { decisions }\end{array}$ & $\begin{array}{c}\text { Some boards shape strategic } \\
\text { decisions }\end{array}$ & $\begin{array}{l}\text { A minority of boards shape } \\
\text { the content, context and } \\
\text { conduct of strategy }\end{array}$ \\
\hline
\end{tabular}

Adapted from McNulty and Pettigrew (1999, p.55). 